\title{
ЗАКОНОДАВЧЕ РЕГУЛЮВАННЯ ПРАВА НАРКОЗАЛЕЖНИХ НА ЛІКУВАННЯ: ВІТЧИЗНЯНИЙ ДОСВІД
}

Шnарага М. Ю.

Статтю присвячено вивченню вітчизняного законодавства стосовно використання й регулювання права осіб, які вживають наркотичні засоби, на медичну допомогу й лікування. Проаналізовано чинні нормативно-правові акти, котрі регулюють питання надання медичної допомоги й лікування осіб, які вживають наркотичні засоби з немедичною метою; звернено увагу на недоліки, що притаманні вітчизняному законодавству. Зроблено висновки щодо необхідності удосконалення вітчизняного законодавства стосовно регулювання права осіб, які вживають наркотичні засоби, на медичну допомогу й лікування, а також розроблення нових нормативно-правових актів і приведення їх у відповідність до міжнародного законодавства.

Ключові слова: наркозлочинність, нормативно-праві акти, наркотичні засоби, особа, медична допомога, лікування.

Статья посвящена изучению отечественного законодательства относительно использования и регулирования права лиц, которые употребляют наркотические вещества, на медицинскую помощь и лечение. Проанализированы действующие нормативно-правовые акты, которые регулируют вопрос предоставления медицинской помощи и лечения лиц, употребляющих наркотические вещества в немедицинских целях; обращено внимание на недостатки, присущие отечественному законодательству. сделаны выводы про усовершенствование отечественного законодательства относительно регулирования права лиц, которые употребляют наркотические вещества, на медицинскую помощь и лечение, а также про разработку новых нормативно-правовых актов и приведение их в соответствие с международным законодательством.

Ключевые слова: наркопреступность, норматив но-правовые акты, наркотические вещества, лицо, медицинская помощь, лечение.

The paper is devoted to the study of domestic legislation regarding the use and regulation of the right of people who use narcotic drugs to medical care and treatment. The current statutory legal acts governing the provision of medical care and treatment of people who use narcotic drugs for non-medical purposes have been analyzed and attention had been drawn to the shortcomings inherent in domestic law. The purpose of this paper is to draw the attention of the state to the problems that exist today in Ukraine, in particular the imperfection of the legislative regulation of the provision of medical care and treatment for people who use narcotic drugs for non-medical purposes, and ways to solve it. A number of statutory legal acts in the law of the drug abusers' treatment have been examined; moreover, international legal documents have been analyzed; the emphasis has been placed on the need to streamline domestic legislation in accordance with international legislation, which, according to the Basic Law of the State of Ukraine, is a part of national legislation.

The author notes that the regulatory framework is quite outdated and not effective enough, therefore there is an urgent

Шпарага М. Ю., 2019 need to develop modern and effective regulatory legal acts, to introduce international norms and standards into national legislation, and to regulate the activities of the National Police, medical institutions in the field of crimes related to drug traffic in gat the legislative level.

In conclusion, taking into account the above, namely, the inadequate state of domestic legislation in the right of people who use narcotic drugs to medical care and treatment, a number of important measures have been proposed, in particular: development and implementation of international experience, various standards, protocols, and recommendations; the creation of medical institutions of a private and state nature; encouraging the public to assist drug abusers; development of new and effective statutory legal acts taking into account international legal experience.

Key words: drug-related crime, statutory legal acts, narcotic drugs, drug abuser, medical care, treatment.

Постановка проблеми. Наркозлочинність $€$ однією 3 найважливіших проблем сучасного суспільства. Враховуючи масовість i стрімке поширення цього виду злочинів, виникає потреба в розробці нормативно-правових актів, котрі надаватимуть можливості для застосування сучасних заходів правового, соціального й медичного характеру з метою впливу на осіб, які вживають наркотичні засоби в немедичних цілях. Постало питання розроблення дієвого механізму й чіткої стратегії для протидії наркозлочинності, яка наділятиме органи Національної поліції, медичні установи правами й обов'язками задля ефективного впливу на осіб, що $\epsilon$ споживачами наркотичних засобів. Одним із дієвих чинників боротьби з наркозлочинністю, на нашу думку, може бути наявність у державі ефективного законодавства, що націлене на якісне регулювання певної сфери відносин. Вітчизняне законодавство у сфері права наркозалежних на лікування не $\epsilon$ досконалим, а в деяких випадках можна стверджувати про його відсутність чи повну неефективність.

Аналіз останніх досліджень і публікацій. Науковий інтерес до проблематики примусового лікування наркозалежних проявили, присвятивши низку праць, багато науковців, зокрема Ю. Баулін, А. Гришко, О. Джужа, А. Закалюк, А. Зелінський, П. Матишевський, А. Музика, В. Сташис, В. Тацій та інші. Їхні дослідження мали надзвичайно важливий вплив на розвиток кримінальних, кримінологічних, соціальних та інших правових питань наркозлочинності.

Метою статті $\epsilon$ намагання звернути увагу на проблеми, котрі існують сьогодні в нашій державі стосовно регулювання права осіб, які вживають наркотичні засоби, на медичну допомогу й лікування. Оскільки, на нашу думку, саме розроблення дієвих і сучасних нормативно-правових актів і впровадження міжнародних норм і стандартів у національне законодавство сприятиме зменшенню кількості осіб, котрі вживають нарко- 
тичні засоби, а в результаті й зниженню рівня наркозлочинності й викоріненню інших суспільних проблем, до яких призводить наркоманія.

Враховуючи ситуацію наркозлочинності в нашій державі, у результаті чого спостерігається стрімкий приріст осіб, що вживають наркотичні засоби й стають наркозалежними, розповсюджуючи інші небезпечні захворювання, створюючи низку суспільних проблем, аналіз вітчизняного досвіду законодавчого регулювання права осіб, які вживають наркотичні засоби, на медичну допомогу й лікування $\epsilon$ надзвичайно актуальним.

Виклад основного матеріалу. Ст. 49 Конституції України гарантує право кожному громадянину на охорону здоров'я, медичну допомогу й медичне страхування. Особи, які споживають наркотичні засоби в немедичних цілях, а саме наркозалежні, не $є$ виключенням, і відповідно, як кожен громадянин нашої держави, мають право на безоплатну медичну допомогу, зокрема лікування.

Вивчаючи вітчизняний досвід, вважаємо за необхідне детально зупинитися на деяких 3 нормативно-правових актів. Це, зокрема, Наказ Міністерства охорони здоров'я України, Міністерства внутрішніх справ України, Генеральної прокуратури України, Міністерства юстиції України від 10 жовтня 1997 р. № 306/680/21/66/5 «Інструкція про порядок виявлення та постановки на облік осіб, які незаконно вживають наркотичні засоби або психотропні речовини»; Наказ Міністерства охорони здоров'я України й Міністерства внутрішніх справ України «Порядок проведення медичного огляду та медичного обстеження осіб, які зловживають наркотичними засобами або психотропними речовинами» від 16 червня 1998 р. №158/417; Стратегія державної політики щодо наркотиків на період до 2020 р.; Єдина Конвенція про наркотичні засоби 1961 р. (з доповненнями) і Конвенція Організації Об'єднаних Націй про боротьбу проти незаконного обігу наркотичних засобів і психотропних речовин; Стандарти надання наркологічної допомоги; Кодекс України про адміністративні правопорушення та Кримінальний кодекс України.

За «Інструкцією про порядок виявлення та постановки на облік осіб, які незаконно вживають наркотичні засоби або психотропні речовини» від 10 жовтня 1997 р. № 306/680/21/66/5 підставою для того, щоби встановити факт вживання наркотичних засобів або психотропних речовин конкретної особи й призначити лікування, $€$ інформація, отримана від підприємств, установ, організацій, засобів масової інформації або окремих громадян. У наступному пункті інструкції вказується достатньо складний і довгий порядок направлення матеріалів до правоохоронних органів, після чого передбачається видача під розписку особі, що перебуває під впливом наркотичних засобів або психотропних речовин, направлення на медичний огляд, де лікар-нарколог приймає рішення щодо обстеження особи [1]. Тобто, аналізуючи цей документ, можна констатувати, що він неефективний і не працює, починаючи з першого суб'єкта, на якого покладено обов'язок передати інформацію щодо особи, котра вживає наркотичні засоби або психотропні речовини чи перебуває в стані наркотичного сп'яніння, оскільки зацікавленими фактично $\epsilon$ лише близькі родичі особи, що вживає наркотичні засоби або психотропні речовини, проте й вони не завжди зацікавлені в розголошенні хворобливого стану близької особи. Варто зауважити, що сьогодні на неофіційному рівні існують так звані громадські організації, діяльність яких спрямована на виявлення осіб, що вживають наркотичні засоби, і передача відповідної інформації до органів Національної поліції. Проте така діяльність законодавчо не врегульована або документи, на підставі яких проводять свою діяльність такі структури, не доведені до широкого загалу.

Також не працює, на нашу думку, i «Порядок проведення медичного огляду та медичного обстеження осіб, які зловживають наркотичними засобами або психотропними речовинами» від 16 червня 1998 р. № 158/417, оскільки, щоб потрапити на лікування до медичного закладу, зацікавленій особі потрібно звернутися до низки установ, що, своєю чергою, через масу негативних чинників, котрі існують у нашій державі, займає велику кількість часу, у результаті чого стає неактуальним i, відповідно, особа втрачає бажання та інтерес до такого роду дій [2]. I тут, здавалося б, єдиним варіантом лікування наркозалежних $€$ приватні установи, проте на сьогодні законодавчо не врегульовано порядок створення таких установ і відповідно відсутнє документальне оформлення потрапляння таких осіб на лікування, Це створює можливість для незаконного існування таких закладів, де не лише безпідставно утримуються пацієнти, а й порушуються права людей, які не мають реальної можливості оскаржити свої права в судовому порядку, оскільки маємо повну відсутність юридичних фактів утримання таких осіб у тих чи інших незаконно створених закладах. Відповідно питання законодавчого регулювання приватних установ, де здійснюється лікування наркозалежних осіб, також потребує законодавчого вирішення.

Проаналізувавши схвалену Кабінетом Міністрів України Стратегію державної політики щодо наркотиків на період до 2020 р. у сфері контролю за обігом наркотиків, боротьби з ї незаконним обігом і протидії наркоманії, що відповідає національним інтересам України і міжнародним конвенціям ООН [3], робимо висновок, що питання, які стосуються лікування й проведення різного роду медичних заходів, певною мірою залишилися поза увагою. Тому маємо потребу в новому документі, сучасному та розробленому на основі реалій сьогодення в суспільстві. Враховуючи той факт, що Україна обрала європейський шлях розвитку, на наш погляд, необхідно переймати досвід іноземних країн, де на відміну від вітчизняного законодавства питання наркозалежних розв'язується не лише шляхом посилення покарання осіб чи впливу на обіг наркотичних засобів, а приділяється увага ще й заходам медичного характеру, які першочергово спрямовані на надання різного роду допомоги, зокрема лікування наркозалежних.

Окрім того, міжнародні акти, що містять низку важливих норм, які стосуються лікування наркозалежних, а саме Єдина Конвенція про наркотичні засоби 1961 р. (з доповненнями) і Конвенція Організації Об'єднаних Націй про боротьбу проти незаконного обігу наркотичних засобів і психотропних речовин, до національного законодавства належним чином не імплементовані, попри те що Україна ратифікувала ці нормативно-правові акти, а ст. 9 Основного Закону проголошує чинні міжнародні договори частиною національного законодавства України. Вважаємо за необхідне впровадити до національного законодавства п. b ст. 3 Конвенції ООН, 
де зазначено можливість сторін передбачати на додаток до засудження або покарання за правопорушення застосовувати до правопорушника заходи лікування; п. с, який передбачає як альтернативу засудженню або покаранню також лікування і подальше спостереження, якщо особа $є$ наркоманом; п. d, що передбачає можливість лікування замість або як доповнення до засудження або покарання особи [4]. Своєю чергою Конвенція 1961 р. містить в ст. 38 важливе положення, що зобов'язує сторони приділяти особливу увагу та здійснювати заходи, що спрямовані на лікування наркозалежних осіб, а також спостереження за ними після лікування; п. 2, на нашу думку також $є$ надзвичайно важливий і потребує імплементації до вітчизняного законодавства, тому що вказує на необхідність підготовки спеціалістів, діяльність яких спрямована на лікування, нагляд і спостереження за наркозалежними особами після закінчення лікування [5].

Варто звернути увагу на те, що в Україні існують Стандарти надання наркологічної допомоги, затверджені Наказом МО3 України й формально обов'язкові для виконання. Проте вони сформульовані в такий спосіб, що дозволяють при тотожних станах застосовувати різні препарати й лікувальні заходи (від замісної терапії до масажу та голковколювання) [6, с. 8]. Лікування наркотичної залежності в Україні проводиться в системі наркологічної допомоги, створеній ще в колишньому СРСР у 1959 р. У ній працюють спеціалізовані наркологічні диспансери й лікарні, а також наркологічні кабінети в лікарнях загального профілю. Ці установи перебувають у муніципальній власності, а методичне керівництво й підготовка нормативних документів покладені на МОЗ України. В роки незалежності в Україні 3'явилися наркологічні кабінети й програми приватної форми власності, але вони надають допомогу наркозалежним в обмеженому обсязі й практично не впливають на ситуацію з громадським здоров'ям, оскільки адресовані найбільш соціально адаптованій частині хворих. Якість надання наркологічної допомоги формально регламентується уніфікованими Стандартами наркологічної допомоги населенню в лікувально-профілактичних установах України. Всі медичні, психологічні й соціально-реабілітаційні програми лікування від наркотичної залежності включено до Тимчасових стандартів діагностично-лікувального процесу стаціонарної допомоги в Україні, затверджених у 1998 р., і Нормативів надання медичної допомоги дорослому населенню в амбулаторно-поліклінічних закладах України, затверджених у 2002 р. Згадані стандарти й нормативи містять різні методи детоксикації, замісну терапію, невідкладну допомогу, психологічні реабілітаційні програми. Водночас, на думку багатьох наркологів, Стандартами майже не користуються [6, с. 15]. Тому спеціалізовані документи $є$ застарілі, вони потребують низки змін, які включатимуть міжнародно-правову практику, будуть уніфікованими й становитимуть єдиний та ефективний перелік медичної допомоги наркозалежним особам.

Складовою частиною сучасного законодавства України, що стосується наркоманії, $\epsilon$ також 17 кримінально-правових норм (ст. ст. 305-321 КК України та ст. ст. 44, 44-1,106-1,106-2 Кодексу України про адміністративні правопорушення). Більшість із них репресивного характеру, спрямована на припинення незаконного обігу наркотиків, обмеження й заборону. Профілактичний характер мають лише ст. ст. 307, 309 і 311 Кримінального Кодексу України [7, с. 41]. Законодавець знову ж таки надає перевагу заходам кримінально-правового впливу, тоді як заходи медичного характеру взагалі залишилися поза увагою, хоча, як зазначено вище, повинні все ж таки бути пріоритетними в боротьбі з наркоманією. Тому маємо потребу в наявності спеціалізованих норм, які поряд (або в сукупності) з заходами кримінально-правового характеру містили б низку профілактичних заходів, зокрема й право на лікування осіб, які вживають наркотичні засоби.

Висновки. Отже, проаналізувавши вищезазначені норми, ми дійшли висновку, що законодавче регулювання права на лікування наркозалежних осіб в Україні перебуває в неналежному стані, а тому, на нашу думку, потребує таких змін:

- створення профільних медичних закладів (як державних, так і приватних) для лікування наркозалежних осіб з використанням сучасних методів допомоги й закріплення їхньої діяльності на законодавчому рівні;

- заохочення громадськості до надання соціальної, психологічної й медичної допомоги наркозалежним особам, а також розроблення документів, на основі яких законодавчо закріплено здійснюватимуть свою роботу громадські організації;

- розроблення на законодавчому рівні нових ефективних нормативно-правових актів, в яких буде імплементовано досвід боротьби європейських країн 3 наркоманією та приділена увага не лише заходам кримінально-правового характеру (наприклад, посилення кримінальної відповідальності), а й нормам профілактичного характеру, що будуть спрямовані на здійснення соціальних і медичних заходів щодо наркозалежних осіб;

- переймання досвіду європейських країн боротьби з наркоманією, що не спрямована лише на заходи примусу;

- впровадження в національне законодавство сучасних європейських стандартів, розроблення різного роду протоколів і рекомендацій.

Отже, застосування законодавцем виключно заходів примусового характеру й посилення кримінальної відповідальності, яка існує та діє сьогодні, сприятиме не боротьбі з наркозлочинністю, а пошуку нових шляхів незаконного обігу та вживання наркотичних засобів, психотропних речовин, їх аналогів або прекурсорів наркозалежними особами, дестабілізації ситуації в державі й поширення інших негативних явищ, які спричинюють наркоманія й наркозлочинність. Враховуючи вищесказане, а саме неналежний стан вітчизняного законодавства у сфері права осіб, які вживають наркотичні засоби, на медичну допомогу й лікування, пропонується низка важливих заходів, зокрема таких, як розробка й упровадження міжнародного досвіду, різного роду стандартів, протоколів і рекомендацій; створення медичних закладів приватного й державного характеру; заохочення громадськості до надання допомоги наркозалежним особам; розробка нових ефективних нормативно-правових актів з урахуванням міжнародно-правового досвіду. 


\section{Література}

1. Про затвердження інструкції про порядок виявлення та постановки на облік осіб, які незаконно вживають наркотичні засоби або психотропні речовини : Наказ Міністерства охорони здоров'я України, Міністерства внутрішніх справ України, Генеральної прокуратури України, Міністерства юстиції України від 10 жовтня 1997 p. № 306/680/21/66/5. URL: https: //zakon.rada.gov.ua/ laws/show/z0534-97.

2. Про затвердження Порядку проведення медичного огляду та медичного обстеження осіб, які зловживають наркотичними засобами або психотропними речовинами : Наказ Міністерства охорони здоров'я України й Міністерства внутрішніх справ України від 16 червня 1998 p. № 158/417. URL: https://zakon.rada.gov.ua/laws/ show/z0482-98.

3. Про схвалення Стратегії державної політики щодо наркотиків на період до 2020 року : Розпорядження Кабінету Міністрів України від 28 серпня 2013 р. № 735-p URL: https://zakon.rada.gov.ua/laws/main/ 735-2013-\%D1\%80.
Протидія злочинності: проблеми практики та науково-методичне забезпечення

4. Конвенція Організації Об'єднаних Націй про боротьбу проти незаконного обігу наркотичних засобів і психотропних речовин. База даних «Законодавство України». URL: https://zakon.rada.gov.ua/laws/main/995_096.

5. Єдина Конвенція про наркотичні засоби 1961 р. 3 поправками, внесеними до неї згідно з Протоколом 1972 р. про поправки до Єдиної конвенції про наркотичні засоби 1961 р. База даних «Законодавство України». URL: https://zakon.rada.gov.ua/laws/main/995_177.

6. Вієвський А.М., Дворяк С.В., Сидяк С.В. Лікування наркозалежності в Україні та оцінка його ефективності. URL: https://www.irf.ua/files/ukr/programs_health_news_ 1477_ua_PR.pdf.

7. Питання сучасної наркополітики України: права людини та доступ до лікування / Одеська правозахисна група «Верітас». Харків : Права людини, 2011. 94 с.

Шпарага М. Ю., аспірантка кафедри кримінального права та кримінології Харківського національного університету внутрішніх справ 